\begin{tabular}{|c|c|}
\hline Title & Interannual variation in solar heating in the Chukchi Sea, A rctic Ocean \\
\hline Author(s) & $\begin{array}{l}\text { T sukada, Y ushiro; U eno, Hiromichi; Ohta, Naoki; Itoh, Motoyo; W atanabe, Eiji; Kikuchi, T akashi; Nishino, Shigeto; } \\
\text { Mizobata, Kohei }\end{array}$ \\
\hline Citation & $\begin{array}{l}\text { Polar Science, 17, 33-39 } \\
\text { https://doi.org/10.1016/.polar.2018.06.003 }\end{array}$ \\
\hline Issue Date & 201809 \\
\hline Doc URL & http:/hdl .handle.net/2115/79184 \\
\hline Rights & (C) 2018, Elsevier. This manuscript version is made available under the CC-BY-NC-ND 4.0 license \\
\hline Rights(URL) & https://creativecommons.org/icenses/by-nc-nd/4.0/ \\
\hline Type & article (author version) \\
\hline File Information & T sukada etal-PS-2018.pdf \\
\hline
\end{tabular}

Instructions for use 


\section{Interannual variation in solar heating in the Chukchi Sea, Arctic Ocean}

2

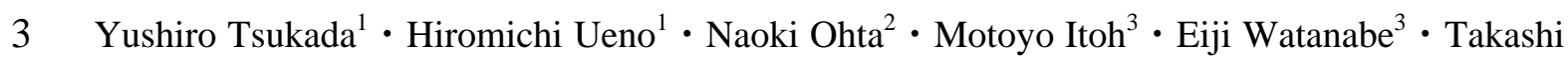

4 Kikuchi $^{3} \cdot$ Shigeto Nishino ${ }^{3} \cdot$ Kohei Mizobata $^{4}$

51 Graduate School of Fisheries Sciences, Hokkaido University, 3-1-1 Minato-cho, Hakodate, 6 041-8611 Japan

72 Graduate School of Environmental Science, Hokkaido University, N10 W5 Kita-ku, Sapporo, 8 060-0810 Japan.

93 Institute of Arctic Climate and Environment Research, Japan Agency for Marine-Earth 10 Science and Technology, 2-15 Natsushima-cho, Yokosuka 237-0061, Japan

114 Department of Ocean Sciences, Tokyo University of Marine Science and Technology, 4-5-7

12 Konan, Minato-ku, Tokyo 108-8477, Japan

13 Author for correspondence: Hiromichi Ueno, Faculty of Fisheries Sciences, Hokkaido 14 University, 3-1-1 Minato-cho, Hakodate, 041-8611 Japan. Email: ueno@fish.hokudai.ac.jp

16 Keywords

17 Solar heating; Chukchi Sea; Interannual variation 
19 Abstract

20 Solar heating in summer in the Chukchi Sea was estimated using satellite-derived sea-ice 21 concentration data and reanalysis shortwave radiation data. The shortwave radiation was 22 validated by in-situ data obtained by the R/V Mirai and NCEP-CFSR/CFSv2 was found to 23 reproduce in-situ data accurately compared with NCEP/NCAR Reanalysis 1 and ERA-Interim.

24 Solar heating integrated over the Chukchi Sea in summer varied interannually from $3.6 \times 10^{20} \mathrm{~J}$ 25 in 2000 to $6.7 \times 10^{20} \mathrm{~J}$ in 2015 , and was up to twice the northward heat flux through the Bering 26 Strait. The total heating in the Chukchi Sea implies that the heat in the Chukchi Sea provided by 27 northward heat flux through the Bering Strait is amplified by solar heating in the Chukchi Sea.

28 We further compared these heat fluxes into the Chukchi Sea with the summertime northward 29 heat flux through Barrow Canyon, an indicator of heat flux from the Chukchi Sea to the Arctic 30 basin. The northward heat flux through Barrow Canyon was affected by the interannual 31 variation of solar heating in the eastern Chukchi Sea. These results imply that modification of 32 Pacific water in the Chukchi Sea by solar heating plays an important role in the interannual 33 variation in heat transport from the Chukchi Sea to the western Arctic basin. 1. Introduction

36 Summer Arctic sea-ice cover has declined rapidly over the past few decades. The albedo of sea 37 ice is much higher than that of open water; a decrease in sea-ice cover is associated with an 38 increase in solar heating and thus surface warming of the Arctic Ocean (Perovich et al., 2007; 39 Steele et al., 2008). The reduction in sea-ice cover also plays a significant role in the polar 
amplification of climate change (Holland and Bitz, 2003; Serreze et al., 2009) and in marine and terrestrial ecological dynamics in the Arctic region (Post et al., 2013).

The largest decline in sea ice occurred in the Pacific region of the Arctic Ocean (Comiso, 2012). Heat transport of Pacific water through the Bering Strait, which has increased in recent years (Woodgate et al., 2006; 2010; 2015), plays an important role in decreasing sea-ice formation during the winter and in sea-ice melt in summer in the Canada basin (Steele et al., 2004; Shimada et al., 2006). In 2007, which was marked by an extreme retreat of Arctic sea ice, the heat transport was sufficient to cause one third of the seasonal Arctic sea-ice loss (Woodgate et al., 2010).

The Chukchi Sea (Fig. 1) is located between the Bering Sea and the Arctic basin and is a pathway for Pacific water from the Bering Strait. We anticipate that solar heating significantly modifies Pacific water in the Chukchi Sea. However, there have been no quantitative analyses of solar heating in the Chukchi Sea except for a rough estimate of $4 \times 10^{20} \mathrm{~J} \mathrm{yr}^{-1}$ (Woodgate et al., 2010) based on an annual solar heating of $~ 1,300 \mathrm{MJ} \mathrm{m}^{-2} \mathrm{yr}^{-1}$ (Perovich et al., 2007) and a

54 Chukchi Sea area of $\sim 350 \times 10^{3} \mathrm{~km}^{2}$. It was also indicated that the annual northward heat flux through the Bering Strait was somewhat greater than annual solar heating in the Chukchi Sea and the former interannual variation was slightly larger than the latter (Woodgate et al., 2010). In this study, we estimated interannual variation in solar heating in summer in the Chukchi Sea by analyzing satellite-derived sea-ice concentration data and reanalysis shortwave radiation data, and compared its impact on the heat budget of the Chukchi Sea with that of heat transport

60 through the Bering Strait after validating the reanalysis data using in-situ shortwave radiation

61 data obtained by the R/V Mirai. 
64 The study area was the Chukchi Sea, comprising the shelf area between the Bering Strait and 65 the western Arctic basin $\left(65.45^{\circ}-75^{\circ} \mathrm{N}, 155^{\circ}-180^{\circ} \mathrm{W}\right.$, excluding the area where water depth was

$66>200$ m, i.e., the area enclosed by the solid black line in Fig. 1). The analysis period was 199967 2015, based on the data available on heat flux through the Bering Strait (Woodgate et al., 2015) 68 and in-situ shortwave radiation, as described below. The solar heating (flux of solar heat input to the ocean, $F_{r w}$ ) was calculated as follows:

$$
F_{r w}=F_{r}(1-\alpha)(1-C) \quad\left[\mathrm{W} \mathrm{m}^{-2}\right]
$$

according to Perovich et al. (2007). In eq. (1), $F_{r}$ is downward shortwave radiation, $\alpha$ is the ocean albedo, and $C$ is the sea-ice concentration. We used a value of 0.07 (Pegau and Paulson, 2001) for ocean albedo $(\alpha)$. We considered only the downward solar energy incident on the open ocean, and neglected the downward solar energy incident on/passing through the sea ice, as in Perovich et al. (2007). Recently, it is indicated that light transmission through sea-ice is important for the near-surface temperature maximum structure in Canada Basin (Jackson et al., 2010) and massive phytoplankton blooms under sea-ice in the northern Chukchi Sea (Arrigo et al., 2012). In the Chukchi Sea, it was reported that annual total solar heating through sea-ice ranges from $0.1 \times 10^{8} \mathrm{Jm}^{-2}$ near the Bering Strait to $1 \times 10^{8} \mathrm{Jm}^{-2}$ in the northern Chukchi Sea (Arndt and Nicolaus, 2014). Since sea-ice concentration in the Chukchi Sea is low in summer especially in the southern part, solar heating through sea-ice was much smaller than cumulative solar heating into open ocean from May to September (3-17 × $10^{8} \mathrm{Jm}^{-2}$, see Fig. 5). Therefore, we neglected light transmission through sea-ice in the present study. 
84 For sea-ice concentration $(C)$, we used daily mean $25 \mathrm{~km} \times 25 \mathrm{~km}$ data generated from satellite 85 passive microwave observations using the NOAA/NSIDC Climate Data Record (Peng et al., 86 2013,

87 https://climatedataguide.ucar.edu/climate-data/sea-ice-concentration-noaansidc-climate-data-rec 88 ord). For downward shortwave radiation $\left(F_{r}\right)$, we used data from the following reanalysis 89 products: (1) NCEP/NCAR Reanalysis 1 (Kalnay et al., 1996, 90 http://www.esrl.noaa.gov/psd/data/gridded/data.ncep.reanalysis.tropopause.html, approximately $912^{\circ} \times 2^{\circ}$, daily), (2) ERA-Interim (Dee et al., 2011, http://www.ecmwf.int, $0.125^{\circ} \times 0.125^{\circ}$, 92 12-hourly) and (3) NCEP-CFSR/CFSv2 (NCEP-CFSR; hereafter, Saha et al., 2010, 93 http://rda.ucar.edu/pub/cfsr.html, about $0.3^{\circ} \times 0.3^{\circ}$ for CFSR (1999-2010), approximately $0.2^{\circ}$ $94 \times 0.2^{\circ}$ for CFSv2 (2011-2015), 6-hourly). We evaluated daily solar heating in the grids of the reanalysis products by linearly interpolating sea-ice concentration data to the grid of the reanalysis product. In the present study, we combined satellite sea-ice concentration data with reanalysis downward shortwave radiation data to estimate solar heating; we did not use net surface shortwave radiation data from reanalysis products. This is because (1) satellite sea-ice

99 concentration data were more accurate than those from reanalysis products and (2) we intended 100 to directly validate reanalysis downward shortwave radiation data with in-situ data as described 101 below.

102 Downward shortwave radiation data differ according to the reanalysis product, particularly at 103 high latitudes, due to the scarcity of in-situ observations. In this study, we used in-situ 104 downward shortwave radiation data obtained by the R/V Mirai (R/V Mirai cruises MR99 105 [September 1999], MR02 [August-October 2002], MR04 [September-October 2004], MR06 106 [August-September 2006], MR08 [August-October 2008], MR09 [September-October 2009], 
and MR10 [September-October 2010]; http://www.godac.jamstec.go.jp/darwin/e) to validate reanalysis shortwave radiation data in the Chukchi Sea, selecting the most suitable reanalysis data set for our study. We first calculated the 24-h averaged in-situ downward shortwave radiation and ship positions (red dots in Fig. 1) from original Mirai data obtained every $10 \mathrm{~min}$.

111 Then, the downward shortwave radiation from the reanalysis products was also 24-h averaged, 112 and linearly interpolated to the positions of the R/V Mirai data. Finally, the two values for the 113 same day and location were compared (176 pairs in total). The in-situ data from the R/V Mirai

114 north of the Chukchi Sea were also used because of the scarcity of in-situ data within the 115 Chukchi Sea itself.

116 We used data from the A3 mooring $\left(66.33^{\circ} \mathrm{N}, 168.96^{\circ} \mathrm{W}, 56 \mathrm{~m}\right.$ depth) $\sim 60 \mathrm{~km}$ north of the

117 Bering Strait (Woodgate et al., 2015, http://psc.apl.washington.edu/HLD/Bstrait/Data/ 118 BeringStraitMooringDataArchive.html) during 1999-2015 to evaluate daily ocean heat 119 transport through the Bering Strait, following Woodgate et al. (2012). The daily heat fluxes 120 through Barrow Canyon during 1999-2014 (Itoh et al., 2013) were also used for comparison 121 with the solar heating. For the latent heat, sensible heat and longwave radiation fluxes, we used 122 the reanalysis data used to estimate solar heating (NCEP-CFSR, see next section). The sea-ice 123 melting heat was calculated from the difference in the daily mean sea-ice concentration 124 averaged over the Chukchi Sea between a given day and the previous day, assuming that the sea-ice thickness was $1 \mathrm{~m}$ and neglecting sea-ice advection. The value of $1 \mathrm{~m}$ is consistent with

126 the average sea-ice thickness of $1.38 \mathrm{~m}$ previously observed in the coastal northeastern Chukchi

127 Sea (Fukamachi et al., 2017) and a value of $~ 1.5 \mathrm{~m}$ that we derived for the Chukchi Sea during 128 March-April using CryoSat-2 data (http://www.cpom.ucl.ac.uk/csopr/seaice.html). Our analysis 129 was limited to the summer season (May-September), neglecting the heat release due to sea-ice 

increase again in October, and heat transport through the Bering Strait is almost zero before May (Fig. 2). In the present paper, integrated values in summer season for the solar heating, heat fluxes and heat transports (with the unit of J) are discussed.

The downward shortwave radiation from the reanalysis products was compared with in-situ data obtained by the R/V Mirai. Figure 3 shows day-to-day variation of downward shortwave radiation from reanalysis products and in-situ observations. This figure indicates that the values from the reanalysis products mostly follows day-to-day variation of in-situ data. The values

140 from the reanalysis products also reproduce decreasing trend of in-situ data during each

141 observation period. However, the averaged downward shortwave radiation using all values in

142 Fig. 3 was 41.0, 41.3, 71.8 and $19.8 \mathrm{~W} \mathrm{~m}^{-2}$ for in-situ observations, NCEP-CFSR, ERA Interim

143 and NCEP-NCAR Reanalysis 1, respectively: the averaged values from ERA Interim and

144 NCEP-NCAR Reanalysis 1 were smaller and larger than that from in-situ data, respectively.

145 The values from the reanalysis products were all significantly correlated with the in-situ values

146 (at the 99\% confidence level, Table 1 and Fig. 4). Figure 4 also shows that the values from ERA

147 Interim and NCEP-NCAR Reanalysis 1 were systematically smaller and larger than in-situ

148 values, respectively, whereas the values from NCEP-CFSR accurately reproduced in-situ data.

149 In addition, the standard deviations of the absolute values of the difference between $\mathrm{in}$-situ and

150 reanalysis values were relatively large for ERA Interim and NCEP-NCAR Reanalysis 1

151 compared with NCEP-CFSR data (Table 1). This finding is consistent with previous studies; 

represented observation data in the Arctic region using two coastal land stations. Therefore, we used NCEP-CFSR downward shortwave radiation data for the analyses below. Although NCEP-CFSR downward shortwave radiation data are concluded to be the most suitable for our analysis based on the comparison with in-situ data discussed above, it is important to note that

157 more in-situ observations and comparison would be necessary to validate the reanalysis data

158 from the view point of interannual variation. We used the latent heat, sensible heat and 159 longwave radiation flux data from NCEP-CFSR to examine the heat budget in the Chukchi Sea

160 although it is also important to note that good reproduction of shortwave radiation does not always indicate the good reproduction of other components.

164 Figure 5 shows the horizontal distribution of cumulative solar heating from May to September 165 in the Chukchi Sea, averaged over 1999-2015 and estimated using NCEP-CFSR downward 166 shortwave radiation data. Solar heating generally decreased with latitude because of early 167 sea-ice retreat and late freezing in the southern region. Strong solar heating was also observed 168 along the Alaskan coast probably due to warm Alaskan coastal current. Solar heating integrated over the Chukchi Sea in summer (from May to September) varied interannually from $3.6 \times 10^{20}$ $\mathrm{J}$ in 2000 to $6.7 \times 10^{20} \mathrm{~J}$ in 2015 (red line in Fig. 6a). This variation was negatively correlated

171 with sea-ice concentration averaged over the Chukchi Sea in summer (blue line in Fig. 6b;

172 correlation coefficient $=-0.91$, significant at the $99 \%$ confidence level), as expected from eq. (1).

173 In contrast, the downward shortwave radiation averaged over the Chukchi Sea in summer was 
174 less variable compared with solar heating, ranging from $171 \mathrm{~W} \mathrm{~m}^{-2}$ in 2011 to $186 \mathrm{~W} \mathrm{~m}^{-2}$ in

1752002 (red line in Fig. 6b), and the correlation coefficient with solar heating was low $(-0.25)$.

176 These results imply that interannual variation in solar heating is influenced by the seasonal

177 timing of open water formation, which is consistent with the result by Steele and Dickinson

178 (2016) that sea surface temperature maximum is correlated with the date of sea-ice retreat in the

179 Pacific Sector of the Arctic Ocean although the correlation coefficient is relatively low in the

180 Chukchi Sea.

181 The summertime solar heating was considerably (1.3- to 1.9-fold) larger than the northward heat

182 flux through the Bering Strait (purple line in Fig. 6a), ranging from $2.4 \times 10^{20} \mathrm{~J}$ in 2012 to 4.7

$183 \times 10^{20} \mathrm{~J}$ in 2007 . The sea-ice melting heat and the sum of the latent heat, sensible heat and

184 longwave radiation fluxes (all of the radiative heat fluxes except for downward shortwave

185 radiation) were less variable throughout the analysis period, ranging from $-2.2 \times 10^{20} \mathrm{~J}$ in 2006

186 to $-1.7 \times 10^{20} \mathrm{~J}$ in 2011 , and $-1.5 \times 10^{20} \mathrm{~J}$ in 2012 to $-0.85 \times 10^{20} \mathrm{~J}$ in 2003 , respectively (Fig. $6 \mathrm{a}$ ).

187 The sea-ice melting heat hardly changes inter-annually because sea-ice usually melts completely

188 in the Chukchi Sea every summer. The summertime total heating in the Chukchi Sea (black line

189 in Fig. 6a) was calculated as the sum of solar heating (red line), northward heat flux through the

190 Bering Strait (purple line), sea-ice melting heat (blue line) and sum of the latent heat, sensible

191 heat and longwave radiation fluxes (green line). The heat transport due to water exchange

192 between the Chukchi Sea and Arctic basin, and between the Chukchi and the East Siberian Seas,

193 was not considered in this analysis.

194 The total heating was positive throughout the analysis period, ranging from $2.9 \times 10^{20} \mathrm{~J}$ in 2000

195 to $8.4 \times 10^{20} \mathrm{~J}$ in 2007 (Fig. 6a). The interannual variation in total heating correlated with the 196 interannual variation in the solar heating (correlation coefficient $=0.94$; significant at the $99 \%$ 
confidence level) and the northward heat flux through the Bering Strait (correlation coefficient

$198=0.89$; significant at the $99 \%$ confidence level). In addition, the interannual variability in the

199 total heating in the Chukchi Sea (standard deviation $=1.6 \times 10^{20} \mathrm{~J}$ ) was roughly twice that of the

200 northward heat flux through the Bering Strait (standard deviation $=0.65 \times 10^{20} \mathrm{~J}$ ) and the solar

201 heating (standard deviation: $0.89 \times 10^{20} \mathrm{~J}$ ). These results imply that the heat in the Chukchi Sea

202 provided by the northward heat flux through the Bering Strait is amplified by solar heating in

203 the Chukchi Sea.

204 It is important to note that these results were not sensitive to sea-ice thickness and ocean albedo,

205 which we assumed in our analysis to be as follows: the correlation coefficients between the

206 interannual variation in total heating and northward heat flux through the Bering Strait were

$2070.91(0.85)$ for a sea-ice thickness $=0.5(2) \mathrm{m}$, and $0.89(0.89)$ for an ocean albedo $=0.0(0.1)$,

208 respectively. The standard deviation of the interannual variability in total heating was roughly

209 twice that of the northward heat flux through the Bering Strait using these values of sea-ice

210 thickness and ocean albedo.

211 It was assumed that the total heating in the Chukchi Sea increased the heat content of the water

212 in the Chukchi Sea or was transported to the Arctic basin. However, it was difficult to separate

213 the two heat fluxes or to clarify how the solar heating in the Chukchi Sea influenced heat

214 transport to the Arctic basin. Therefore, we used the summertime northward heat flux through

215 Barrow Canyon (Fig. 6b), one of the major heat transport fluxes from the Chukchi Sea to the

216 Arctic basin (Itoh et al., 2013; Watanabe et al., 2017), to investigate the influence of solar

217 heating in more detail. The summertime mean Pacific water transport through Barrow Canyon

218 represents more than $80 \%$ of the long-term mean Pacific water inflow through the Bering Strait

219 (Itoh et al., 2013). The northward annual heat transport through the Barrow Canyon ranges from 

the Chukchi Sea, probably because the total heating is mostly used to heat the water in the Chukchi Sea.

223 Comparison between Fig. 6a and 6c shows that the interannual variation in the northward heat

224 flux through Barrow Canyon did not correlate with that through the Bering Strait (correlation 225 coefficient $=0.16$ ), implying that the northward heat flux through the Bering Strait does not 226 control the interannual variation in the northward heat flux through Barrow Canyon. However, 227 the correlation coefficient between the northward heat flux through Barrow Canyon and the solar heating in the Chukchi Sea was 0.65, significant at 95\% confidence level. This implies that the solar heating in the Chukchi Sea has a significant impact on the interannual variation in heat transport from the Chukchi Sea to the Arctic basin. While the northward heat flux through Barrow Canyon did not correlate with that through the Bering Strait, the former correlated with the solar heating in the Chukchi Sea, because the residence time for the water in the Chukchi Sea is longer than several months (e.g. Watanabe, 2011).

234 The correlation coefficients between the northward heat flux through Barrow Canyon and the 235 solar heating distributed from the Bering Strait to the Barrow Canyon were high $(>0.5)$ in the eastern Chukchi Sea (Fig. 7). This area corresponds to one of three flow paths from the Bering Strait to the Arctic basin (Alaskan Coastal Current; e.g., Weingartner et al., 2005), implying that solar heating along the Alaskan Coastal Current from the Bering Strait to the Barrow Canyon has a significant impact on the interannual variation in the northward heat flux through Barrow

240 Canyon. The area where the correlation coefficient $>0.5$ also extended to the 241 west/west-northwest from the canyon. This pattern of distribution of the correlation coefficient 242 might correspond to the flow path from the area around the Hanna Shoal to Barrow Canyon in 
243 Gong and Pickart (2015), who reported that this flow originated from the other flow paths from

244 the Bering Strait: through the Hope Valley into Herald Canyon (Weingartner et al., 1998), and

245 through the Central Channel between the Herald and Hanna Shoals (Weingartner et al., 2005).

246 These results imply that modification of Pacific water by solar heating in the Chukchi Sea plays

247 an important role in interannual variation in heat transport from the Chukchi Sea to the Arctic

248 basin. A more recent study indicates the existence of a westward current from the Barrow

249 Canyon (Chukchi slope current, Corlett and Pickart, 2017); therefore, interannual variation of

250 northward heat flux through Barrow Canyon might further propagate westward along the 251 continental slope.

252

253

254 5. Summary

255 We estimated interannual variation in solar heating in the Chukchi Sea via analysis of 256 satellite-derived sea-ice concentration data and shortwave radiation reanalysis data. The 257 downward shortwave radiation from the reanalysis products was compared with in-situ data 258 obtained by the R/V Mirai. We concluded that NCEP-CFSR data reproduced in-situ data most accurately, and used NCEP-CFSR downward shortwave radiation data in our analyses.

260 Summertime solar heating integrated over the Chukchi Sea varied interannually from $3.6 \times 10^{20}$

$261 \mathrm{~J}$ in 2000 to $6.7 \times 10^{20} \mathrm{~J}$ in 2015. The previous estimate of $4 \times 10^{20} \mathrm{~J}$ (Woodgate et al., 2010)

262 was included in this range but was on the low end of the variability. The summertime solar

263 heating was negatively correlated with summertime sea-ice concentration averaged over the 
Chukchi Sea and was considerably (1.3- to 1.9-fold) larger than the northward heat flux through

265 the Bering Strait. The summertime total heating in the Chukchi Sea, calculated as the sum of 266 solar heating, northward heat flux through the Bering Strait, sea-ice melting heat, and latent heat, 267 sensible heat and longwave radiation fluxes, was positive throughout the analysis period, 268 ranging from $2.9 \times 10^{20} \mathrm{~J}$ in 2000 to $8.4 \times 10^{20} \mathrm{~J}$ in 2007 . The interannual variation in total 269 heating was significantly correlated with the interannual variation in solar heating, as well as 270 with the northward heat flux through the Bering Strait. In addition, the interannual variability in 271 the total heating in the Chukchi Sea was roughly twice that of the northward heat flux through 272 the Bering Strait and the solar heating. These results imply that the heat in the Chukchi Sea 273 provided by the northward heat flux through the Bering Strait is amplified by solar heating in 274 the Chukchi Sea.

275 We used the summertime northward heat flux through Barrow Canyon, one of the major heat 276 fluxes from the Chukchi Sea to the Arctic basin, to investigate the influence of solar heating in 277 more detail. The interannual variation in the northward heat flux through Barrow Canyon was 278 not correlated with that though the Bering Strait. In contrast, the northward heat flux through 279 Barrow Canyon was significantly correlated with solar heating in the Chukchi Sea, especially 280 along the flow paths from the Bering Strait to Barrow Canyon. This implies that modification of 281 Pacific water in the Chukchi Sea by solar heating plays an important role in heat transport from 282 the Chukchi Sea to the Arctic basin. 
Arrigo, K. R., Perovich, D. K., Pickart, R. S., Brown, Z. W., van Dijken, G. L., Lowry, K. E., 293 Mills, M. M., Palmer, M. A., Balch, W. M., Bahr, F., Bates, N. R., Benitez-Nelson, C., 294 Bowler, B., Brownlee, E., Ehn, J. K., Frey, K. E., Garley, R., Laney, S. R., Lubelczyk, L., 295 Mathis, J., Matsuoka, A., Mitchell, B. G., Moore, G. W. K., Ortega-Retuerta, E., Pal, S., 296 Polashenski, C. M., Reynolds, R. A., Schieber, B., Sosik, H. M., Stephens, M., and Swift, J. 297 H., 2012. Massive Phytoplankton Blooms Under Arctic Sea Ice, Science, 336, 1408-1408, 298 doi:10.1126/Science.1215065.

299 Arndt, S. and Nicolaus, M., 2014. Seasonal cycle and long-term trend of solar energy fluxes 300 through Arctic sea ice, The Cryosphere, 8, 2219-2233, 301 https://doi.org/10.5194/tc-8-2219-2014.

302 Comiso, J. C., 2012. Large decadal decline of the Arctic multiyear ice cover. J. Clim. 25, 11763031193.

304 Corlett, W. B., Pickart, R. S., 2017. The Chukchi slope current. Prog. Oceanogr. 153, 50-65. 305 doi:10.1016/j.pocean.2017.04.005 
Dee, D. P., Uppala, S. M., Simmons, A. J., Berrisford, P., Poli, P., Kobayashi, S., Andrae, U.,

307 Balmaseda, M. A., Balsamo, G., Bauer, P., Bechtold, P., Beljaars, A. C. M., van de Berg, L.,

308 Bidlot, J., Bormann, N., Delsol, C., Dragani, R., Fuentes, M., Geer, A. J., Haimberger, L.,

309 Healy, S. B., Hersbach, H., Holm, E. V.,' Isaksen, L., Ka llberg, P., Kohler, M., Matricardi,

310 M., McNally, “ A. P., Monge-Sanz, B. M., Morcrette, J. J., Park, B. K., Peubey, C., de

311 Rosnay, P., Tavolato, C., Thepaut, J. N., and Vitart, F., 2011. The ERA-Interim reanalysis:

312 configuration and performance of the data assimilation system, Q. J. Roy. Meteor. Soc., 137,

$313 \quad 553-597$.

314 Fukamachi, Y., Simizu, D., Ohshima, K., Eicken, H., Mahoney, A., Iwamoto, K., Moriya E.,

315 Nihashi, S., 2017. Sea-ice thickness in the coastal northeastern Chukchi Sea from moored

316 ice-profiling sonar. Journal of Glaciology, 63(241), 888-898. doi:10.1017/jog.2017.56

317 Gong, D., Pickart, R. S., 2015. Summertime circulation in the eastern Chukchi Sea. Deep-Sea 318 Research II 118, 18-31.

319 Holland, M. M., Bitz, C. M., 2003. Polar amplification of climate change in coupled models, 320 Clim. Dynam., 21, 221-232.

Itoh, M., Nishino, S., Kawaguchi, Y., Kikuchi, T., 2013. Barrow Canyon volume, heat, and freshwater fluxes revealed by long-term mooring observations between 2000 and 2008, J. Geophys. Res. Oceans, 118, 4363-4379, doi:10.1002/jgrc.20290.

324 Jackson, J. M., Carmack, E. C., McLaughlin, F. A., Allen, S. E., Ingram R. G., 2010. 325 Identification, characterization, and change of the near-surface temperature maximum in the 326 Canada Basin, 1993-2008, J. Geophys. Res., 115, C05021, doi:10.1029/2009JC005265. 
Kalnay, E., Kanamitsu, M., Kistler, R., Collins, W., Deaven, D., Gandin, L., Iredell, M., Saha, S., White, G., Woollen, J., Zhu, Y., Leetmaa, A., Reynolds, B., Chelliah, M., Ebisuzaki, W., Higgins, W., Janowiak, J., Mo, K., Ropelewski, C., Wang, J., Jenne, R., Joseph, D., 1996. The NCEP/NCAR 40-Year Reanalysis Project. Bull. Amer. Meteor. Soc., 77, 437-471.

Lindsay, R., Wensnahan, M., Schweiger, A., Zhang, J., 2014. Evaluation of seven different atmospheric reanalysis products in the Arctic, J. Climate, https://doi.org/10.1175/JCLI-D-13-00014.1

Pegau, W. S., Paulson, C. A., 2001. The albedo of Arctic leads in summer, Annals of Glaciology, 33, 221-224.

Peng, G., Meier, W. N., Scott, D. J., Savoie, M. H., 2013. A long-term and reproducible passive microwave sea ice concentration data record for climate studies and monitoring, Earth Syst. Sci. Data, 5, 311-318, https://doi.org/10.5194/essd-5-311-2013

Perovich, D. K., Light, B., Eicken, H., Jones, K. F., Runciman, K., Nghiem, S. V., 2007. Increasing solar heating of the Arctic Ocean and adjacent seas, 1979-2005: attribution and role in the ice-albedo feedback, Geophys. Res. Lett., 34, L19505, doi:10.1029/2007GL031480.

Post, E., Bhatt, U. S., Bitz, C. M., Brodie, J. F., Fulton, T. L., Hebblewhite, M., Kerby, J., Kutz, S. L., Stirling, I., Walker, D. A., 2013. Ecological consequences of sea ice decline, Science, 341, 519-524, doi:10.1126/science.1235225.

Saha, S., Moorthi, S., Pan, H.-L., Wu, X., Wang, J., Nadiga, S., Tripp, P., Kistler, R., Woollen, J., Behringer, D., Liu, H., Stokes, D., Grumbine, R., Gayno, G., Wang, J., Hou, Y.-T., Chuang, H.- Y., Juang, H.-M. H., Sela, J., Iredell, M., Treadon, R., Kleist, D., Van Delst, P., 
349 Keyser, D., Derber, J., Ek, M., Meng, J., Wei, H., Yang, R., Lord, S., Van Den Dool, H.,

350 Kumar, A., Wang, W., Long, C., Chelliah, M., Xue, Y., Huang, B., Schemm, J.-K., Ebisuzaki,

351 W., Lin, R., Xie, P., Chen, M., Zhou, S., Higgins, W., Zou, C.-Z., Liu, Q., Chen, Y., Han, Y.,

352 Cucurull, L., Reynolds, R. W., Rutledge, G., and Goldberg, M., 2010. The NCEP climate

353 forecast system reanalysis, B. Am. Meteorol. Soc., 91, 1015-1057,

354 doi:10.1175/2010BAMS3001.1.

355 Serreze, M. C., Barrett, A. P., Stroeve, J. C., Kindig, D. M., Holland, M., 2009. The emergence 356 of surface-based Arctic amplification, Cryosphere, 3, 9-11.

357 Shimada, K., Kamoshida, T., Itoh, M., Nishino, S., Carmack, E., McLaughlin, F., Zimmermann, 358 S., Proshutinsky, A., 2006. Pacific Ocean inflow: Influence on catastrophic reduction of sea 359 ice cover in the Arctic Ocean, Geophys. Res. Lett., 33, L08605, doi:10.1029/2005GL025624.

360 Steele, M., Morison, J., Ermold, W., Rigor, I., Ortmeyer, M., Shimada, K., 2004. Circulation of 361 summer Pacific halocline water in the Arctic Ocean, J. Geophys. Res., 109, C02027, 362 doi:10.1029/2003JC002009.

363 Steele, M., Ermold, W., Zhang, J., 2008. Arctic Ocean surface warming trends over the past 100 364 years, Geophys. Res. Lett., 35, L02614, doi:10.1029/ 2007GL031651.

365 Steele, M., and Dickinson S., 2016. The phenology of Arctic Ocean surface warming, J. 366 Geophys. Res. Oceans, 121, 6847-6861, doi:10.1002/ 2016JC012089.

367 Watanabe, E., 2011. Beaufort shelf break eddies and shelf-basin exchange of Pacific summer 368 water in the western Arctic Ocean detected by satellite and modeling analyses, J. Geophys. 369 Res., 116, C08034, doi:10.1029/2010JC006259. 
Watanabe, E., Onodera, J., Itoh., M., Nishino, S., Kikuchi, T., 2017. Winter transport of subsurface warm water toward the Arctic Chukchi Borderland, Deep Sea Research Part I, 128, 115-130, doi:10.1016/j.dsr.2017.08.009.

Weingartner, T. J., Cavalieri, D. J., Aagaard, K., Sasaki, Y., 1998. Circulation, dense water formation, and outflow on the northeast Chukchi shelf. J. Geophys. Res., 103, 7647-7661.

Weingartner, T., Aagaard, K., Woodgate, R., Danielson, S., Sasaki, Y., Cavalieri, D., 2005. Circulation on the north central Chukchi Sea shelf. Deep-Sea Res. II. 52(24-26), 3150-3174. doi:10.1016/j.dsr2.2005.10.015.

Woodgate, R. A., Aagaard, K., Weingartner, T. J., 2006. Interannual changes in the Bering Strait fluxes of volume, heat and freshwater between 1991 and 2004, Geophys. Res. Lett., 33, 15609, doi:10.1029/2006GL026931.

Woodgate, R. A., Weingartner, T., Lindsay, R., 2010. The 2007 Bering Strait oceanic heat flux and anomalous Arctic sea-ice retreat, Geophys. Res. Lett., 37, 01602, doi:10.1029/2009GL041621.

Woodgate, R. A., Weingartner, T. J., Lindsay, R., 2012. Observed increases in Bering Strait oceanic fluxes from the Pacific to the Arctic from 2001 to 2011 and their impacts on the Arctic Ocean water column, Geophys. Res. Lett., 39, L24603, doi:10.1029/2012GL054092.

Woodgate, R.A., Stafford, K.M., Prahl, F.G., 2015. A synthesis of year-round interdisciplinary mooring measurements in the Bering Strait (1990-2014) and the RUSALCA years (20042011). Oceanography 28(3):46-67. 

reanalysis products.

\begin{tabular}{|l|c|c|c|}
\hline & NCEP-CFSR & ERA Interim & NCEP-NCAR \\
& $0.81^{*}$ & $0.81^{*}$ & $0.75^{*}$ \\
\hline Correlation & & & 18.71 \\
\hline Standard deviation of \\
absolute value of
\end{tabular}

* Significant at the $99 \%$ confidence level.

Fig. 1 Bottom topography (m) of the Chukchi Sea. The area enclosed by the solid black line 398 indicates the area analyzed in this study $\left(65.45^{\circ}-75^{\circ} \mathrm{N}, 155^{\circ}-180^{\circ} \mathrm{W}\right.$ excluding the area 399 where water depth $>200 \mathrm{~m}$ ). Red dots indicate the locations of in-situ downward shortwave 400 radiation observations by R/V Mirai (in 1999, 2002, 2004, 2006, 2008, 2009, and 2010) $401 \quad$ averaged over 24 hours.

402 Fig. 2 (a) Seasonal variation in sea-ice concentration averaged over the Chukchi Sea during 403 1999-2015 (black solid line) with \pm 1 standard deviation from interannual variability (blue 404 bars). (b) Seasonal variation in northward heat transport through the Bering Strait (TW) 405 averaged during 1999-2015 (black solid line) with \pm 1 standard deviation (red bars) 
406

407

408

409

410

411

412

413

414

415

416

417

418

419

420

421

422

423

424

425

426

427

Fig. 3 Day-to-day variation of in-situ downward shortwave radiation obtained by R/V Mirai (black lines $\mathrm{W} \mathrm{m}^{-2}$ ) and downward shortwave radiation from NCEP-CFSR (red lines), ERA-Interim (purple lines) and NCEP/NCAR Reanalysis 1 (blue lines) $\left(\mathrm{W} \mathrm{m}^{-2}\right)$ in (a) 1999, (b) 2002, (c) 2004, (d) 2006, (e) 2008, (f) 2009 and (g) 2010.

Fig. 4 Scatterplot of in-situ downward shortwave radiation obtained by R/V Mirai $\left(\mathrm{W} \mathrm{m}^{-2}\right)$ and downward shortwave radiation from (a) NCEP-CFSR, (b) ERA-Interim and (c) NCEP/NCAR Reanalysis $1\left(\mathrm{~W} \mathrm{~m}^{-2}\right)$.

Fig. 5 Horizontal distribution of cumulative solar heating from May to September in the Chukchi Sea averaged over 1999-2015 $\left(10^{8} \mathrm{Jm}^{-2}\right)$ estimated using NCEP-CFSR downward shortwave radiation data.

Fig. 6 (a) Interannual variation in solar heating (red), total heating (black), sea-ice melting heat (blue), and the sum of the sensible heat (SH), latent heat (LH) and longwave radiation (LW) fluxes (green) integrated in the Chukchi Sea from May to September $\left(10^{20} \mathrm{~J}\right)$. Purple line indicates northward heat flux through the Bering Strait (BSHF) integrated from May to September. (b) Interannual variation in downward shortwave radiation (red line, $\mathrm{W} \mathrm{m}^{-2}$ ) and the sea-ice concentration (blue line) averaged in the Chukchi Sea during May-September. (c) Interannual variation in northward heat flux through Barrow Canyon integrated from May to September $\left(10^{20} \mathrm{~J}\right)$.

Fig. 7 Horizontal distribution of the correlation coefficient between the interannual variations in solar heating in each grid integrated from May to September and northward heat flux through Barrow Canyon integrated from May to September. Correlation coefficients of 0.5 and 0.75 mostly correspond to $90 \%$ and $99 \%$ confidence levels, respectively. 
429 The English in this document has been checked by at least two professional editors, both

430 native speakers of English. For a certificate, please see:

431 http://www.textcheck.com/certificate/Xni0ez

432

433 


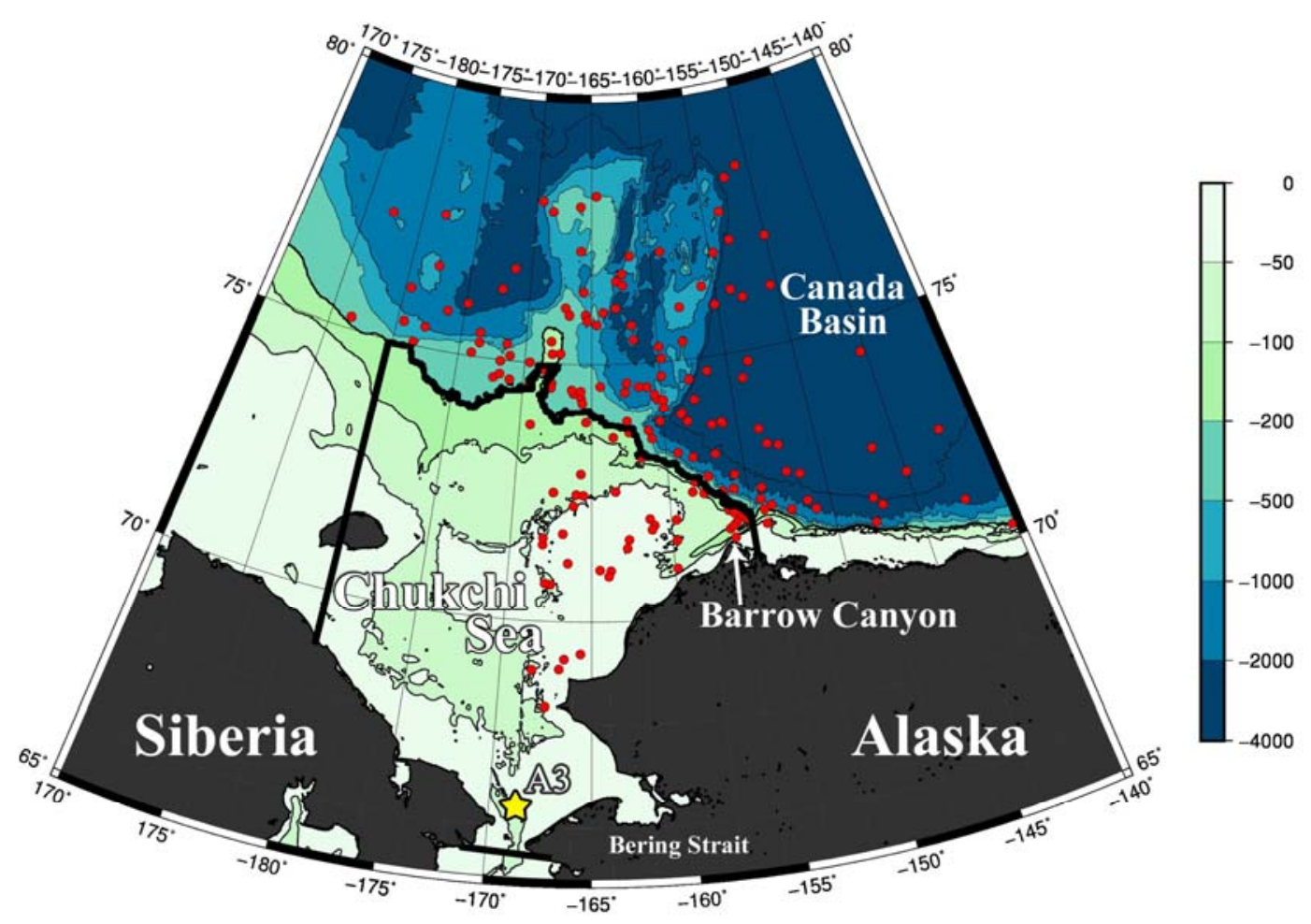

436 Fig. 1 Bottom topography (m) of the Chukchi Sea. The area enclosed by the solid black line 437 indicates the area analyzed in this study $\left(65.45^{\circ}-75^{\circ} \mathrm{N}, 155^{\circ}-180^{\circ} \mathrm{W}\right.$ excluding the area 438 where water depth $>200 \mathrm{~m}$ ). Red dots indicate the locations of in-situ downward shortwave 439 radiation observations by R/V Mirai (in 1999, 2002, 2004, 2006, 2008, 2009, and 2010) 440 averaged over 24 hours. 
(a) Sea ice concentration

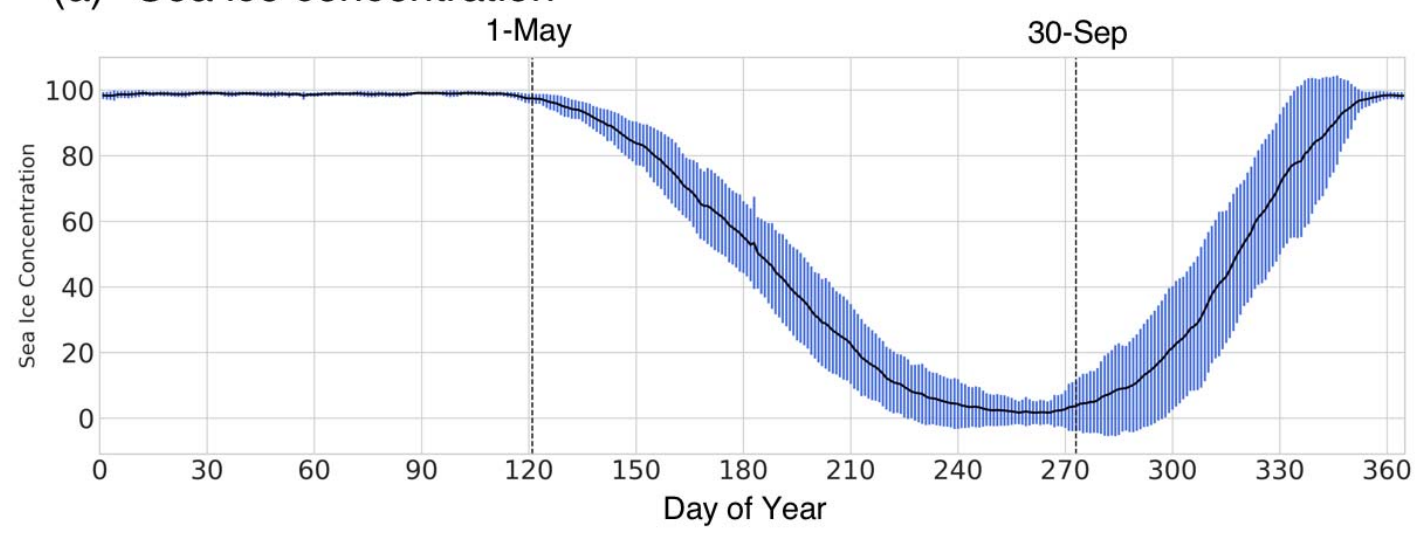

(b) Heat transport through the Bering Strait (TW)

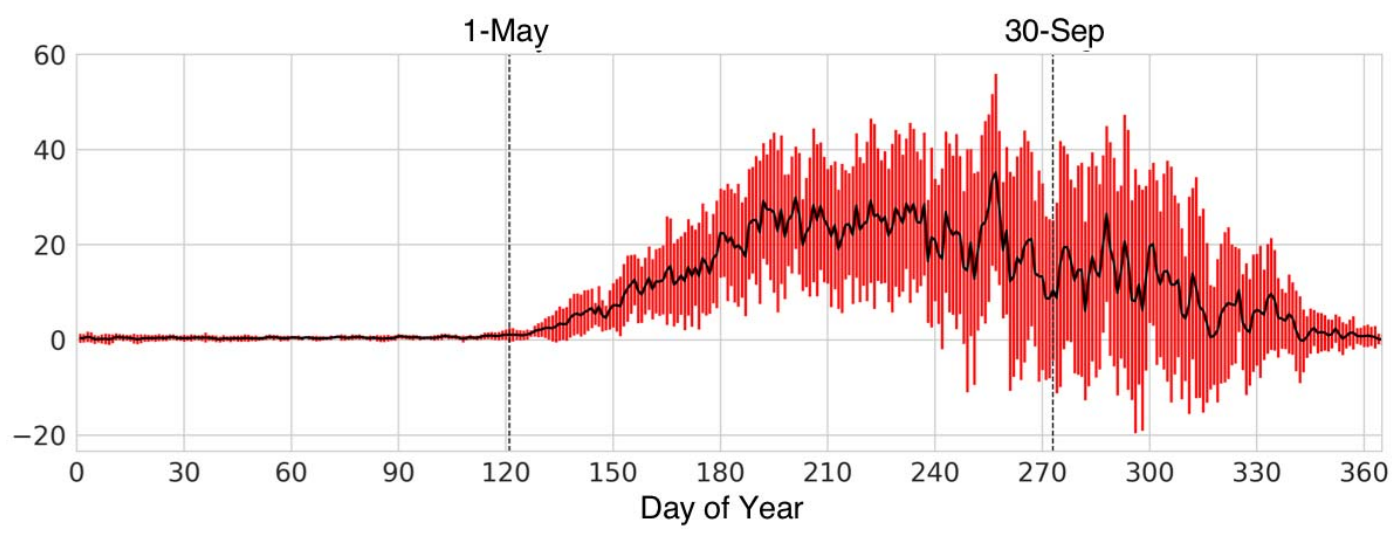

443 Fig. 2 (a) Seasonal variation in sea-ice concentration averaged over the Chukchi Sea during

444 1999-2015 (black solid line) with \pm 1 standard deviation from interannual variability (blue

445 bars). (b) Seasonal variation in northward heat transport through the Bering Strait (TW)

446 averaged during 1999-2015 (black solid line) with \pm 1 standard deviation (red bars) 
(a)1999

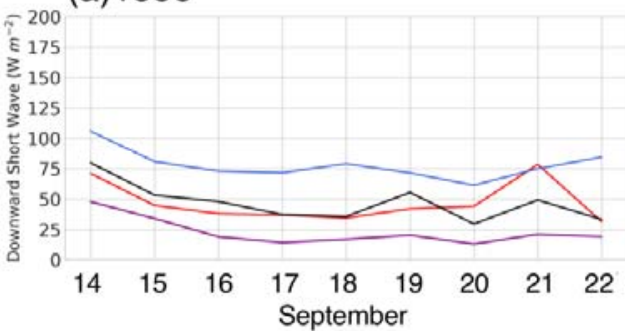

(c) 2004

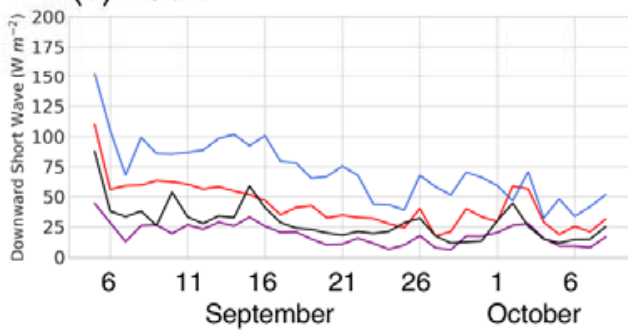

(e) 2008

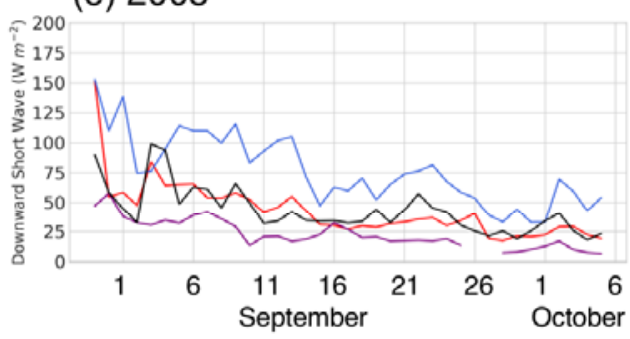

(g) 2010

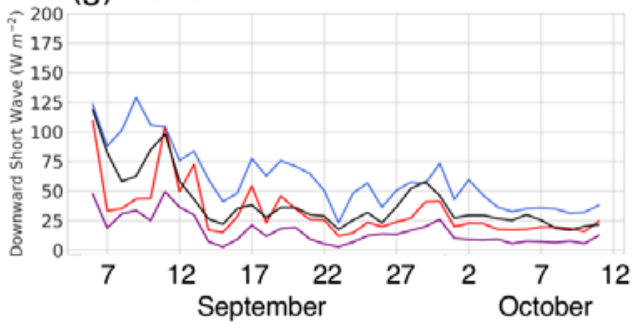

(b) 2002

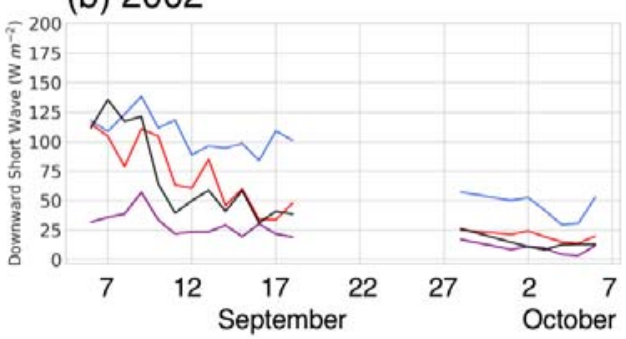

(d) 2006

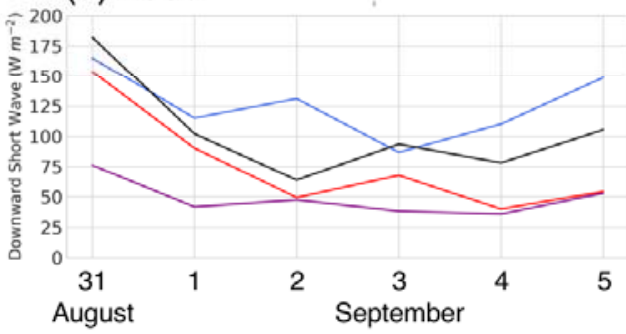

(f) 2009

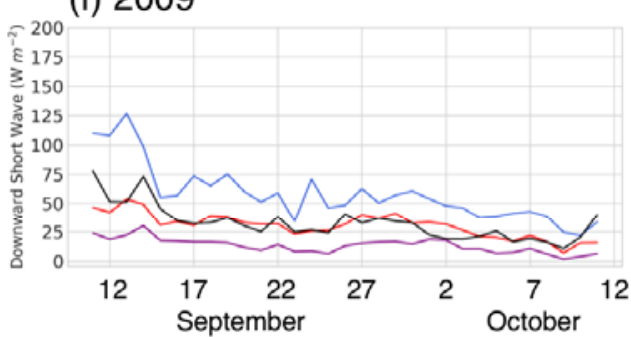

- in-situ observations

- NCEP-CFSR

- ERA Interim

- NCEP-NCAR Reanalysis 1

449 Fig. 3 Day-to-day variation of in-situ downward shortwave radiation obtained by R/V Mirai

450 (black lines $\mathrm{W} \mathrm{m}^{-2}$ ) and downward shortwave radiation from NCEP-CFSR (red lines),

451 ERA-Interim (purple lines) and NCEP/NCAR Reanalysis 1 (blue lines) ( $\mathrm{W} \mathrm{m}^{-2}$ ) in (a) 1999,

452

(b) 2002, (c) 2004, (d) 2006, (e) 2008, (f) 2009 and (g) 2010. 
(a) NCEP-CFSR

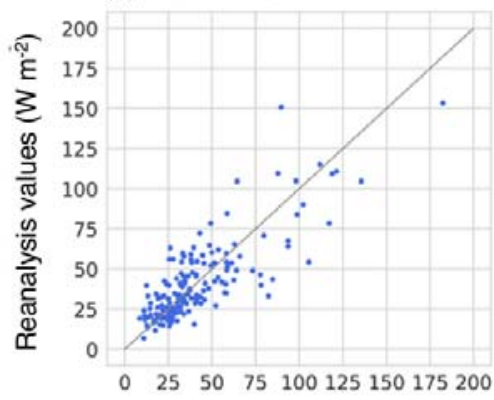

(b) ERA-Interim

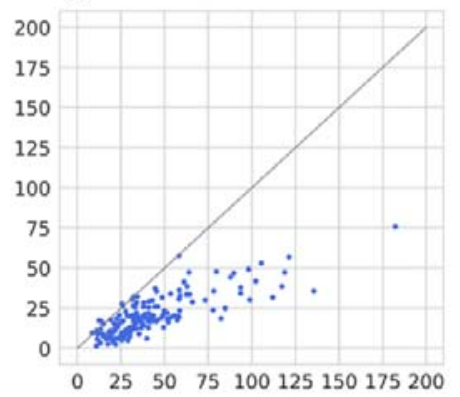

(c) NCEP/NCAR Reanalysis 1

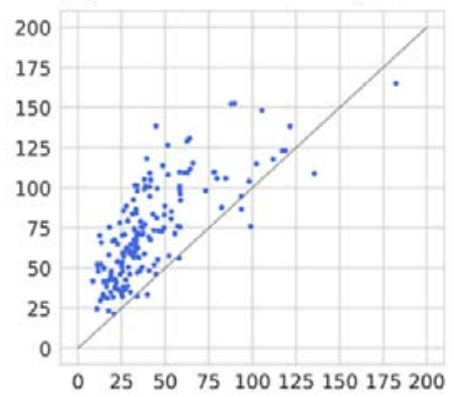

454 In-situ incident shortwave radiation by $\mathrm{R} / \mathrm{V}$ Mirai $\left(\mathrm{W} \mathrm{m}^{-2}\right)$

455 Fig. 4 Scatterplot of in-situ downward shortwave radiation obtained by R/V Mirai $\left(\mathrm{W} \mathrm{m}^{-2}\right)$ and

456 downward shortwave radiation from (a) NCEP-CFSR, (b) ERA-Interim and (c) NCEP/NCAR 457 Reanalysis $1\left(\mathrm{~W} \mathrm{~m}^{-2}\right)$.

458

459 


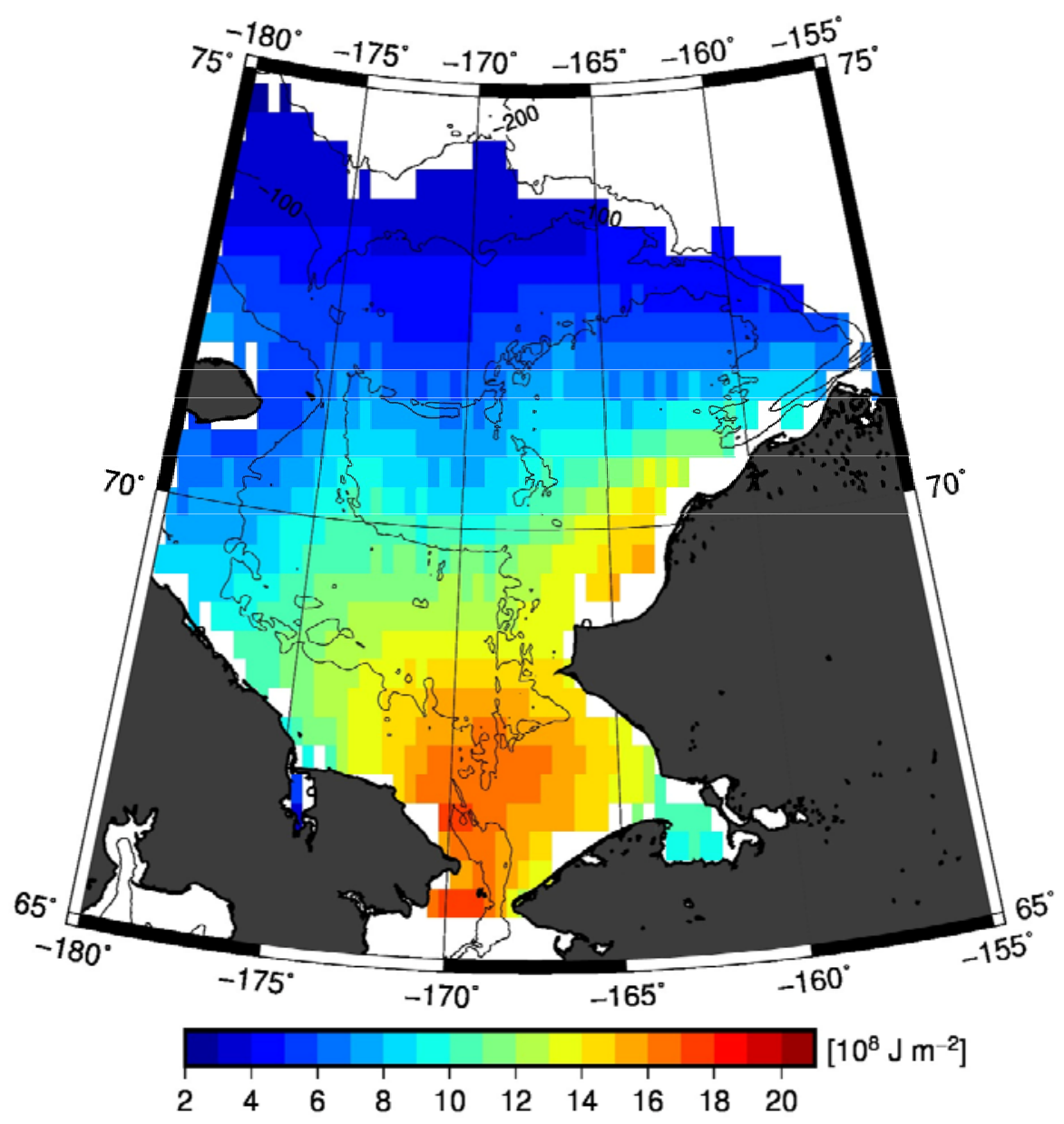

460

461 Fig. 5 Horizontal distribution of cumulative solar heating from May to September in the 462 Chukchi Sea averaged over 1999-2015 $\left(10^{8} \mathrm{Jm}^{-2}\right)$ estimated using NCEP-CFSR downward 463 shortwave radiation data.

464

465 
(a)

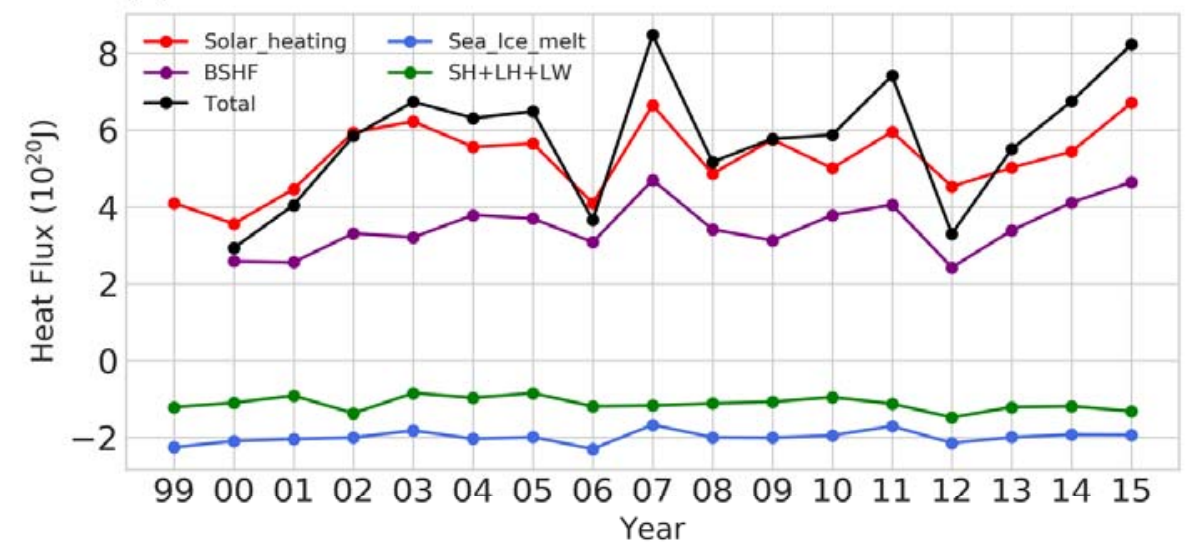

(b)

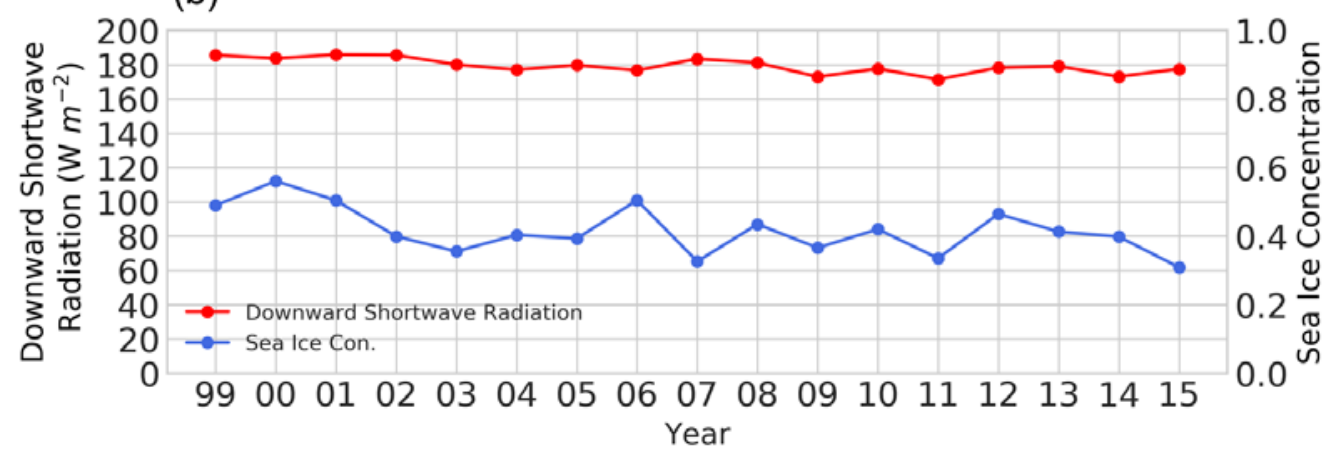

(c)

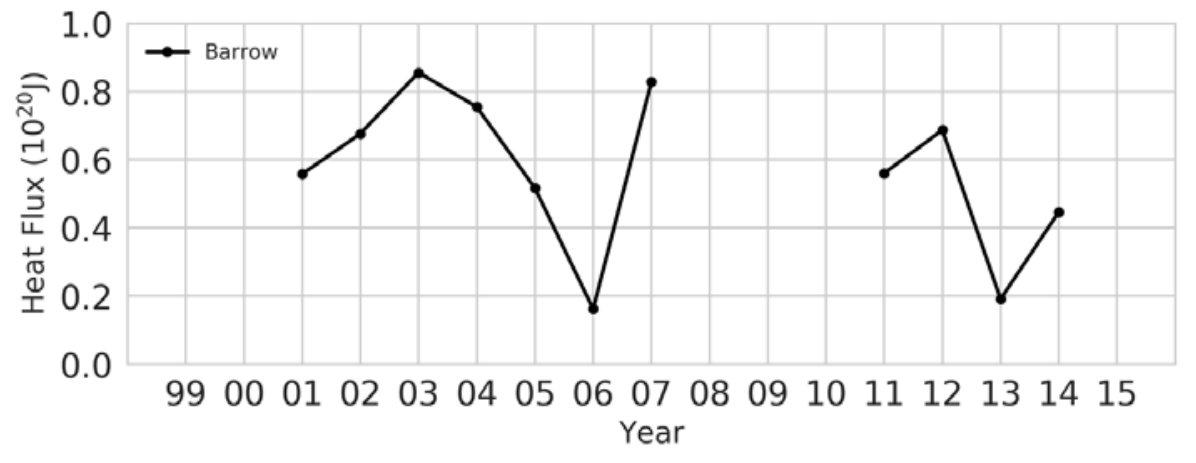

Fig. 6 (a) Interannual variation in solar heating (red), total heating (black), sea-ice melting heat (blue), and the sum of the sensible heat (SH), latent heat (LH) and longwave radiation (LW) fluxes (green) integrated in the Chukchi Sea from May to September $\left(10^{20} \mathrm{~J}\right)$. Purple line indicates northward heat flux through the Bering Strait (BSHF) integrated from May to September. (b) Interannual variation in downward shortwave radiation (red line, $\mathrm{W} \mathrm{m}^{-2}$ ) and the sea-ice concentration (blue line) averaged in the Chukchi Sea during May-September. (c) Interannual variation in northward heat flux through Barrow Canyon integrated from May to 474 September $\left(10^{20} \mathrm{~J}\right)$. 


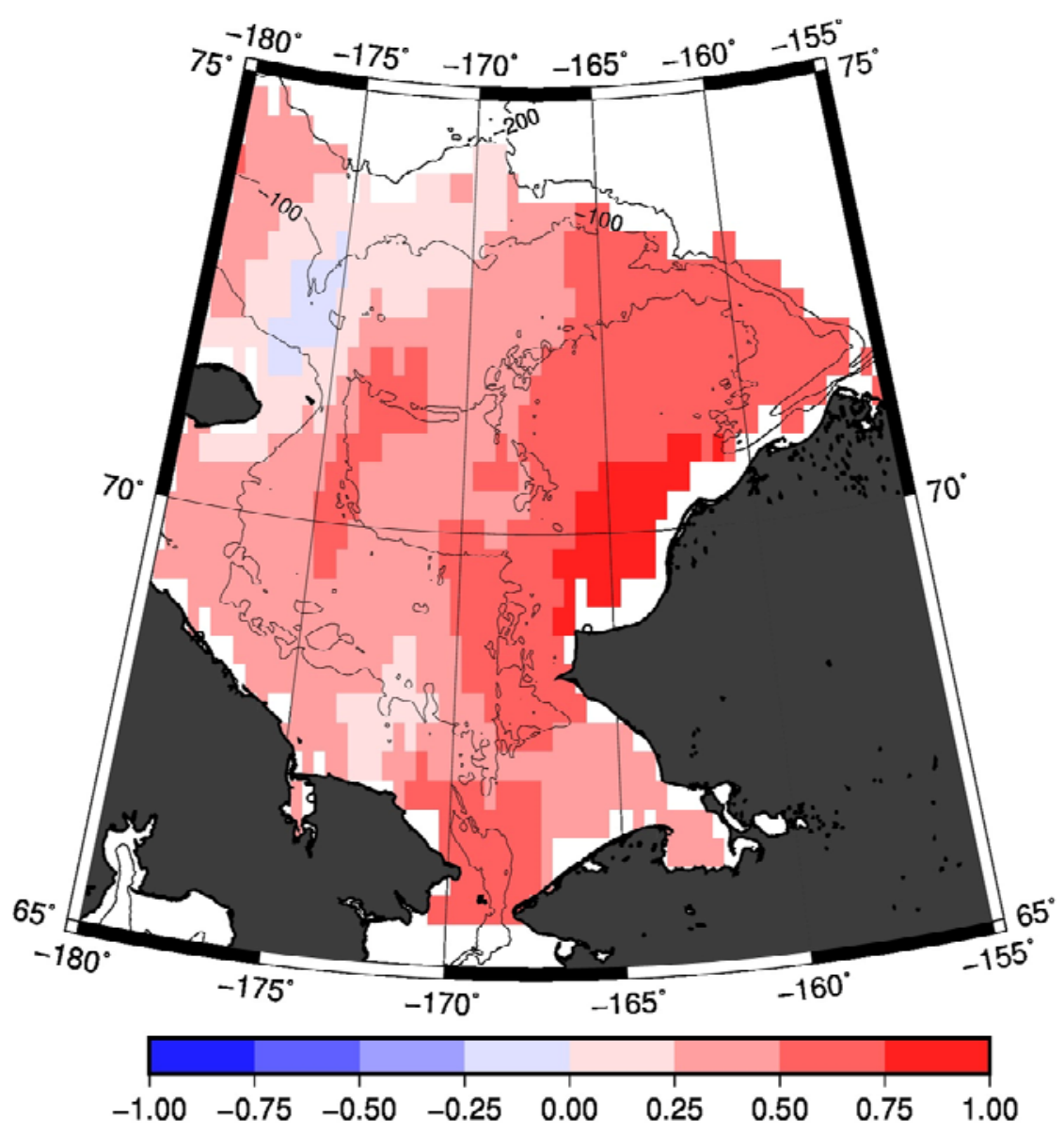

478 Fig. 7 Horizontal distribution of the correlation coefficient between the interannual variations in

479 solar heating in each grid integrated from May to September and northward heat flux through

480 Barrow Canyon integrated from May to September. Correlation coefficients of 0.5 and 0.75

481 mostly correspond to $90 \%$ and $99 \%$ confidence levels, respectively. 